\title{
Dynamic Model Of Trochus niloticus. Linn, In Resources Management, In Coastal Area Of Saparua Island, Saparua SubDistrict, Central Maluku Regency
}

\author{
F.S. Tuhumury \\ Faculty of Fisheries and Marine Sciences Pattimura University Mr. Chr. Soplanit Street Campus Poka, Ambon- \\ Indonesia 97233
}

\begin{abstract}
This study is conducted in Saparua Island, Saparua Sub-district, Central Maluku Regency. This study aims to build dynamic model on the basis of bioecological, social-economy-cultural, law and institutional condition. The steps to build this model are the needs analysis, problem formulation, system identification, model validation and model sensitivity testing. For this study, two sub-models are built which are called bioecological sub-model and bioecological, social-economy-cultural, law and institutional sub-model. This study concludes that the created model explains a condition if the coral reef condition is maintained in a good to an excellent condition, T.niloticus population can be fixed which will also raise its recruitment rate. Otherwise, if the sasi and law implementation performance are increased, T.niloticus population and fisherman income will also raise.
\end{abstract}

Keywords: Dynamic model, cultivation management, T.niloticus, Saparua Island

\section{Introduction}

One of the sizable famous marine resources which gets the world attention is T.niloticus (Trochus niloticus), and Indonesia is one of the T.niloticus producing countries in the world [10] (Hoang et al, 2008). In 1979, production of T.niloticus in Saparua lola Island reaches 4 ton [1] (Arifin, 1993), while in 1989 in Maluku, production of T.niloticus reaches 251 ton which is equivalent to USD 691,900 ( \pm IDR6.8 billion) and in 2005, this production drastically falls into 14.2 ton [5] (Fisheries and Marine Services of Maluku Province, 2006). In Saparua Island in 2008, production of T.niloticus also falls into <1.5 ton [14] (Soparue, 2008). The high sales value and demand on T.niloticus play an important role in the income of Maluku community. However, the high sales value and demand on T.niloticus, indeed, motivate the people to keep exploiting T.niloticus intensively with an effect of over fishing occurred in almost all regions in Maluku.

T.niloticus production decline relates to its habitat damage. It is known that T.niloticus lives in the reef flat starting from intertidal zone to subtidal zone, especially for the coral reef which had been grown by red algae (Cyanophycea and Phaeophycea), benthic diatom and foraminifera [3] (Calquhoun, 2001). T.niloticus is a kinds of herbivore species which its viability depends on coral reef integrity. Other than the place to live, to forage and to breed, coral reef is also a growth place of various seaweed which belongs to the food of T.niloticus. Thereby, the damage of coral reef ecosystem will directly affect on the food chain in this ecosystem which will ultimately affect on T.niloticus population.

Other than bioecological aspect, aspect of social-economy-cultural, law and institutional which is related to management of coastal and marine natural resources belongs to an important part in analyzing causal factors of T.niloticus production decline in Maluku waters area, especially in Saparua Island.

Based on the observation, region implementing local wisdom system these days is a region with continuous production decline of T.niloticus. Hence, this study re-investigates the management system based on local wisdom in bioecological perspective of T.niloticus, social-economy-cultural, law and institutional aspect of the people. Furthermore, the whole result of the study/analysis from the proposed aspects above become the data and information for analysis of coastal and marine natural resources management model in general and build a specific dynamic model based on bioecological, social-economy-cultural, law and intitutional condition for the interest of T.niloticus resources management comprehensively in coastal waters of Saparua Island. 
Location and Time of Study

\section{Research Method}

This study is conducted from January to December, 2010 in Saparua Island waters, Maluku (Figure 1).

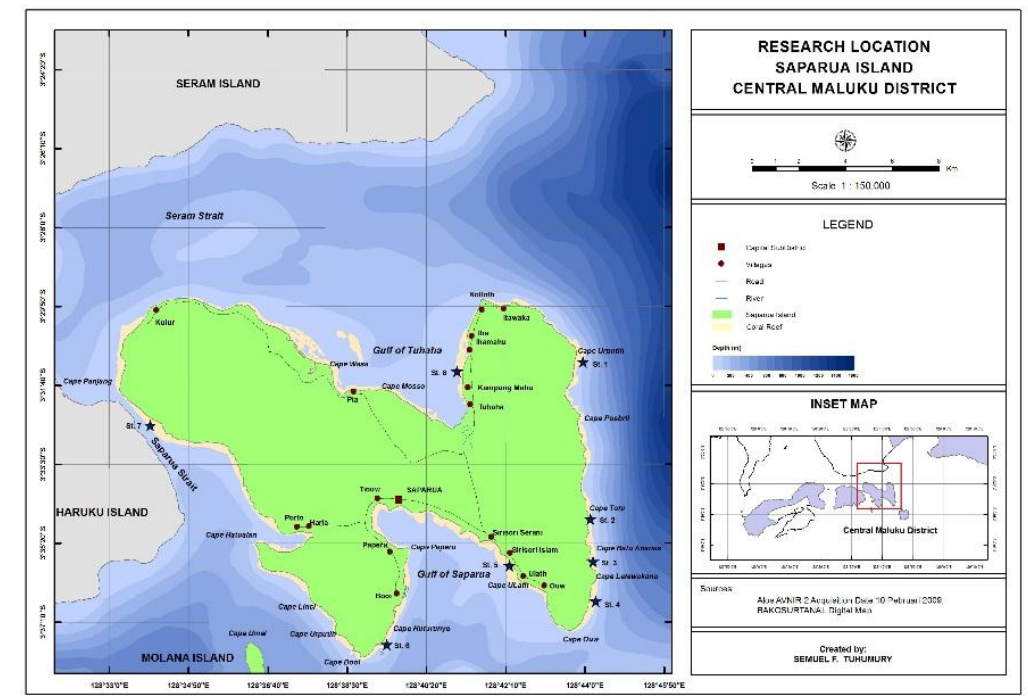

Figure 1. Research Location Map of Coastal Area in Saparua Island, Saparua Sub-district, Central Maluku Regency

\section{Data Sampling}

This study needs parameter data of waters physical-chemical characteristics, biological resources of T.niloticus, social-economy-cultural, law and institutional condition. Collected data is taken from primary and secondary data.

\section{Build a Dynamic Model for T.niloticus Resources Management}

Dynamic System Analysis

Based on the complex and dynamic problem characteristics and multi-dimension, a symbolic model use is determined. In building the needed model, it uses software called Powersim version 2.5c. [10] Forrester (1961). In [1] Eriyatno (2003), system approach is a method to solve problems starting from identification for a number of needs, thus it produces an operation over an effective system. Thereby, analysis on problems by this system approach should meet the characteristics of: (1) complex, where the interaction of some elements are quite complex, (2) dynamic, where some factors are changing over time and there is an assumption in the future and (3) probabilistic, i.e. the need of opportunity function in conclusion interference or recommendation.

While the steps to build this model are explained below:

a)Necessity Analysis

This step should reflect the needs of everyone/every institution who is involved in the determined system. Every system actor has different needs, thus they can affect system performance [8] (Hartrisari 2007). Based on the result of field observation, it is gained a number of needs from the policy maker in level of province, regency/town, sub-district and village, community (in common and for the fisherman) who are involved in management system of T.niloticus and its habitat.

b) Problems Formulation

Coastal resources management meets the criteria as a complex and dynamic system management. Some parties maybe see that coastal and marine waters as a simple and static thing. However, there are some related interests within this coastal and marine ecosystem. Based on the needs description above, problems of coastal resources management especially for T.niloticusin coastal waters of Saparua Island can be formulated as follow:

1. There had been an ecological disturbance in the habitat which causes production decline of T.niloticus resources living in coastal waters of Saparua Island,

2. The high degree of T.niloticus resources exploitation from the local nature by local community had caused production decline.

3. The weak power of the existing law system for years had caused production decline of T.niloticus resources, and 
4. The weak power of inter-institution or concerned institution coordination in developing natural and environmental resources in Saparua Island.

\section{c)System Identification}

Eriyatno (2003) states that a connection chain between the needs statement of system actors and specific statement of problems which should be solved in order to meet the need belongs to the system identification steps which are regularly illustrated by cause-effect diagram or input-output diagram. The residents of coastal waters often use fishing gear equipments which are hostile-environment for fishing, especially those which are operated in coral reef area. Continuous exploitation effect of T.niloticus can destroy the coral reef ecosystem as the habitat of this species.

\section{d). Model Validation}

Validation is the last step in model development to investigate this model whether the model output is in accordance with the real system or not by observing corresponding internal consistency and representation [2]. According to [4], validation in dynamic system modeling can be conducted by some methods consisting of direct structural testing without running the model, structural testing of model behavior by running the model, and by comparing the model behavior with the real system.

Validation in this modeling is conducted by comparing modeled behavior and the real system which is known as AME testing (Absolut Mean Error) developed by Barlas (1996) in [12] Muhammadi et al (2001). AME is deviation statistical testing between the average value of simulation and the actual value ranging from 5 to $10 \%$

$$
\begin{array}{ll}
\mathrm{AME}=(\mathrm{Si} & -\mathrm{Ai}) / \mathrm{Ai} \quad \text { x } \quad 100 \% \\
\text { information: } & \mathrm{Si}=\mathrm{Si} / \mathrm{N} ; \\
& \mathrm{Ai}=\mathrm{Ai} / \mathrm{N} ; \\
& \mathrm{S}=\mathrm{Simulation} \text { value; } \\
& \mathrm{A}=\text { Actual value. }
\end{array}
$$

\section{e. Model Sensitivity Testing}

Model sensitivity is a model response toward a stimulus. Response is shown by giving treatment and/or model performance. Stimulus is given by providing certain treatment to model elements/structures. Sensitivity testing aims to explain parameter sensitivity, variable and relationship of inter-variable in the model. Result of this sensitivity testing whether in the form of behavior changes and/or model performance are used to analyze intervention effect toward the model [12].

\section{Results And Discussion}

Causal Loop Diagram of T.niloticus Resources Management Model

To analyze a complex system, the dynamic system becomes an alternative method. This analysis is conducted by grounding on the information guide which is showed in cause-effect or causal loop diagram. This diagram is a technique to illustrate feedback information working in a system [7]. "Causal" refers to the relationship of problems/causes and its effect, while "loop" refers to nodal problems and closed effect. The symbol of (+) or (-) at the tip of arrow depends on its positive or negative effect in causal factors. Symbol of (+) explains a causeeffect relationship where the both variables change its direction to the same aim and (-) symbol means a relationship between two variables in the loop showing a counter aim. Then, to build T.niloticus management model in coastal waters of Saparua Island, identified variables information which had been connected to causal loop in general as explained above is illustrated in Figure 2. Furthermore, in the building framework for T.niloticus resources management model, all of identified variables in causal loop diagram below will be separated into two sub-models i.e. bioecological, social-economy-cultural, law and institutional submodel. 


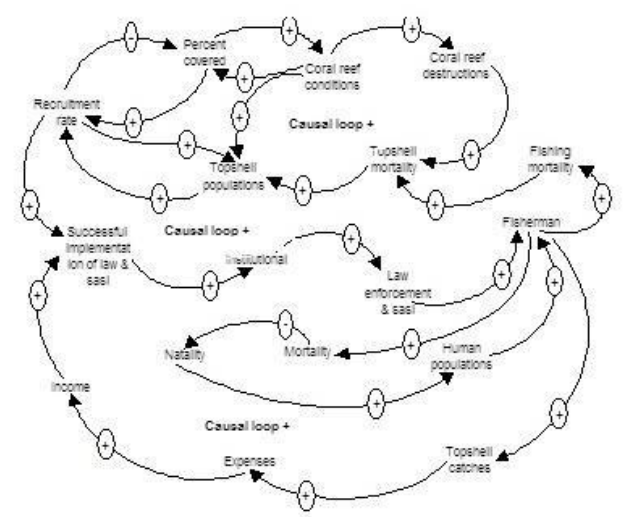

Figure 2. Causal loop of T.niloticus resources management model

in coastal waters of Saparua Island (CR: Coral Reef (ID: Terumbu Karang/TK); Rt: Rate (ID: Laju/Lj); Law (ID: Undang-Undang/UU)

\section{Model Description}

Weakening of T.niloticus population in coastal waters of Saparua Island is one of the complex system problems engaging multiple interacting variable components therein. T.niloticus population decline in coastal waters of Saparua Island can be viewed as a problem of system dynamics which are changed over time and affected by dynamic factors.

T.niloticus is one of the important fishery resources for Saparua Island community. The high market demand and selling price of T.niloticus brings this snail to have an important role in elevating economic capacity of the people. The aim of T.niloticus resources management modeling is to know how this T.niloticus population can be increased in the future which will be utilized in sustainable manner to meet the economic needs of coastal community in Saparua Island.

The built dynamic system model is restricted to factors which give a strong effect to the system. T.niloticus management model is built on bioecological, social-economy-cultural, law and institutional basis to protect T.niloticus in coastal waters of Saparua Island. It consists of two sub-models, i.e. bioecological submodel and bioecological, social-economy-cultural, law and institutional sub-model.

\section{Bioecological Sub-model}

Bioecological sub-model depicts T.niloticus population changes which are affected by coral reef conditional factors or variables. Bioecological sub-model explains biological condition of T.niloticus population, i.e. recruitment rate, population and mortality raise. While the ecological aspect is more emphasized on coral reef conditional aspects as T.niloticus habitat which are represented by coral cover condition, coral damage level or utilization activity of the other marine resources including T.niloticus. The built bioecological sub-model refers to the response of coral reef damage level at the range from poor, fair, good to excellent condition toward T.niloticus population changes in the nature under assumption that physical-chemical parameter of the waters is relatively experiencing a significant fluctuation with coral reef condition or snail population. This assumption is built due to study location condition which is relatively opened and directly opposite to Banda Sea, thus the analyzed physical-chemical parameter tends to be affected by water mass of Banda Sea.

It is gained from the study that temperature distribution in coastal waters of Saparua Island is ranging from 29 to $30^{\circ} \mathrm{C}$, salinity is ranging from 33 to $34 \%$ and DO is ranging from 4.12 to $7.30 \mathrm{mg} / \mathrm{l}$. [15] in their research find that temperature becomes one of the most affected factors in lola life, especially in consuming the oxygen. Temperature at $31{ }^{\circ} \mathrm{C}$ is an optimum temperature for the process. Then, [9] proposes that temperature difference also affects lola growth especially if it relates to its abundance and natural food quality. Temperature tolerance for T.niloticus life ranges from 28 to $34^{\circ} \mathrm{C}$. T.niloticus belongs to respiroregulator organism

T.niloticus, as a living creature in the sea water has tolerance to salinity changes with range of 31 to 37 $\%$. Thereby, it can be said that value range of water quality in coastal waters of Saparua Island is relatively normal and tolerable for T.niloticus (Figure 3). Based on the description above, it can be said that if the more precise T.niloticus bioecological sub-model is implemented specifically for T.niloticus starting from juvenil to the mature level by grounding on the concerned physical-chemical and oceanographical factors in some references, most of its phases are intended for planktonic or veliger phase. Planktonic or veliger phase is a phase in organism cycle which is still sensitive to quality changes of waters environment parameter because the parameter changes can affect its animal welfare.

\section{Bioecological, Social-Economy-Cultural, Law and Institutional Sub-model}

Bioecological, social-economy-cultural, law and institutional sub-model depicts T.niloticus population condition no matter on the recruitment or mortality rate which is not affected by natality rate, mortality rate and population amount in Saparua Island. This assumption is made because it is only the inhabitants working as 
fisherman who give contribution to T.niloticus population changes, while the physical-chemical aspect of the waters is assumed in constant condition. This assumption explains that T.niloticus population condition no matter for its recruitment rate, natural mortality rate and mortality as the consequence of fishing are affected by sasi and law implementation. Then, law and institution performance improvement can help in increasing economic capacity of fisherman's family. Income variable is affected by income and expenditure variables of the fisherman, while the income variable is also affected by the success of sasi and law implementation (Figure 4).

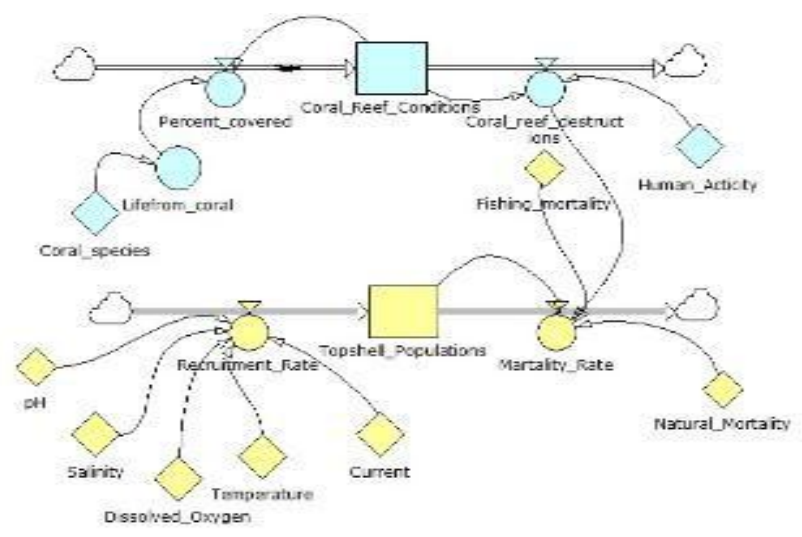

Figure 3.T.niloticus bioecological sub-model ( $\mathrm{CR}=$ Coral Reef;

$\mathrm{Rt}=$ Rate PCC $=$ Percentage of Coral Cover;

$\mathrm{CRD}=$ Coral Reef Damage;

$\mathrm{NR}=$ Natural Resources; DO= Dissolved Oxygen)

T.niloticus bioecological sub-model depicts a condition if the optimization of law and institution implementation continues, fishing activity which is conducted by the fisherman can be done based on the determined fishing schedule when T.niloticus reaches its proper size, thus it will raise the selling price and will increase the fisherman income compared with the previous period. Based on the simulation result, it can be explained that improvement of institution and law system performance will very profitable for T.niloticus conservation. However, it is known that a complex system needs management model as the system simplification. Yet, this model performance will be more effective if all of the built sub-models are activated collectively.

Those two bioecological sub-model and bioecological, social-economy-cultural, law and institutional sub model are the designed dynamic model for T.niloticus management which had experienced production decline. However, this dynamic model will be implemented in juvenil to mature phase only.

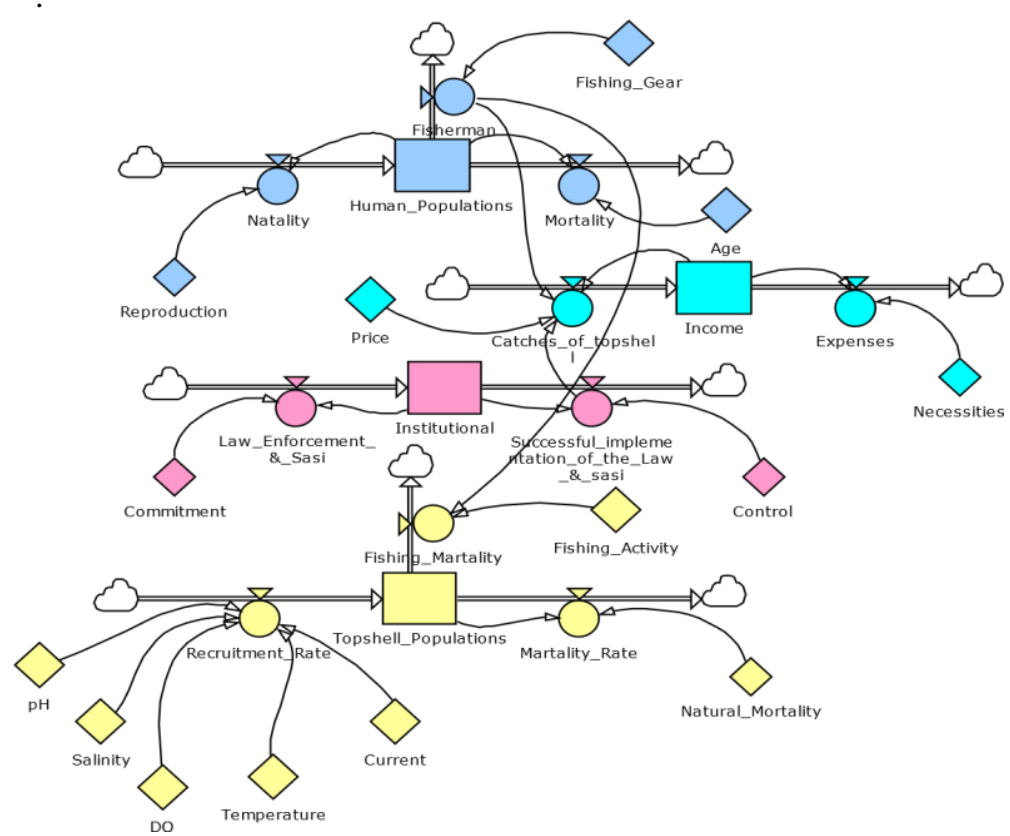

Figure 4. Bioecological, social-economy-cultural, law and institutional sub-model (Lw= Law; Rt= Rate; FM= Fishing Mortality; LI= Law Implementation) 


\section{Base Scenario Simulation for T.niloticus Management Policy Making}

This designed model becomes a scenario-making basis with a created simulation trial phase series, thus it enables the model to be implemented in the real condition.

Otherwise, in connecting between the arranged scenario and the created model, there will be conducted an interpretation of factor condition into the model, thus the concerned scenario can be simulated [13]. Scenario analysis is conducted toward some variables that enables them to be implemented in the real world, they are T.niloticus population, T.niloticus recruitment rate and coral reef condition (in bioecological sub-model), T.niloticus population and fisherman income (in bioecological, social-economy-cultural, law and institutional sub-model).

Capability of T.niloticus resources management system in producing demanded output can be analyzed by some indicators as the capability measure by running the model. Scenario simulation in this study combines percentage quantity (\%) depicting coral reef condition and sasi and law implementation toward T.niloticus resources (individual $/ \mathrm{km}^{2}$ ), its recruitment rate (individual/year) and fisherman income. It is presumed that this developed scenario simulation will get different response over inter-scenario. Output combination from coral reef condition with sasi and law implementation and population, recruitment and fisherman income are aimed to gain information on the importance of coral reef ecosystem for T.niloticus life and the importance of sasi and law implementation to protect T.niloticus resources from over-utilization.

Some reasons on the basis of coral reef condition and sasi and law implementation which become one of the components in making management scenario are: 1) coral reef becomes one of the ecosystems as the habitat and place of activities for various marine biota including T.niloticus; 2) there are many arranged legislations to protect T.niloticusresources whether the formal legislation or the traditional ones, but in fact they had not implemented optimally. Thus, T.niloticusresources management in comprehensive manner highly needs these two inputs as the arranged scenario basis.

\section{Scenario of Coral Reef Condition: Poor (<24,9\%); Fair (25-49\%); Good (50-74,9\%) and Excellent (>75\%)}

The existing T.niloticus population progress and success of recruitment in coastal waters of Saparua Island at poor coral reef condition declines until the lowest limit. Result of scenario analysis in 2011 asserts that T.niloticus population was 19,203 individual $/ \mathrm{km}^{2}$ and its success of recruitment was 17,498 individual/year by an increase of 19,612 individual $/ \mathrm{km}^{2}$ and 17,871 individual/year. In 2015 , it is presumed that it will decrease into 18,826 individual $/ \mathrm{km}^{2}$ and 17,154 individual/year in 2021 (Table 1). Then, if this coral reef condition is slowly fixed to a fair condition until the good condition for T.niloticus population and recruitment, there will be individual amount raise continuously. T.niloticus population in 2021 will raise into 628,782 individual $/ \mathrm{km}^{2}$, while the recruitment will raise into 572,946 individual/year (Table 1).

Table 1. Result of population simulation and recruitment rate based on the poor and the fair coral reef condition changes

\begin{tabular}{ccccc}
\hline \multirow{2}{*}{ Year } & \multicolumn{4}{c}{ Conditions of Coral Reefs } \\
\cline { 2 - 5 } & \multicolumn{2}{c}{ Poor $=<24,9 \%$} & \multicolumn{2}{c}{ Fair $=25-49 \%$} \\
\cline { 2 - 5 } & $\begin{array}{c}\text { Population } \\
\left.\text { (individu/km }{ }^{2}\right)\end{array}$ & $\begin{array}{l}\text { Rekriutmen rate } \\
\text { (individu/year) }\end{array}$ & $\begin{array}{c}\text { Population } \\
\left.\text { (individu/km }{ }^{2}\right)\end{array}$ & $\begin{array}{c}\text { Rekriutmen rate } \\
\text { (individu/year) }\end{array}$ \\
\hline 2011 & 19.203 & 17.498 & 19.203 & 17.498 \\
2012 & 19.374 & 17.653 & 27.335 & 24.907 \\
2013 & 19.500 & 17.768 & 38.874 & 35.422 \\
2014 & 19.579 & 17.841 & 55.233 & 50.328 \\
2015 & 19.612 & 17.871 & 78.402 & 71.440 \\
2916 & 19.598 & 17.858 & 11.186 & 101.313 \\
2017 & 19.537 & 17.802 & 157.531 & 143.542 \\
2018 & 19.428 & 17.703 & 222.982 & 203.181 \\
2019 & 19.273 & 17.561 & 315.326 & 287.325 \\
2020 & 19.072 & 17.378 & 445.490 & 405.930 \\
2021 & 18.826 & 17.154 & 628.782 & 572.946 \\
\hline
\end{tabular}

Then, if coral reef condition is in good or excellent condition, it will bring a huge effect on T.niloticus population condition and recruitment level. T.niloticus population will increase in 10 years period (2021) to 2,408,345 individual $/ \mathrm{km}^{2}$ and for the excellent coral reef condition it will reach $3,898,404$ individual $/ \mathrm{km}^{2}$. The same condition also occurred for recruitment level that in good coral reef condition, it reached from 17,498 individual/year in 2011 to 2,194,493 individual/year in 2012. Then, for the excellent coral reef condition in 2012, it increased to 3,552,226 individual/year (Table 2). 
Table 2. Result of population simulation and recruitment rate based on the good and the excellent coral reef condition changes

\begin{tabular}{|c|c|c|c|c|}
\hline \multicolumn{5}{|c|}{ Conditions of Coral Reefs } \\
\hline \multirow[t]{2}{*}{ Year } & \multicolumn{2}{|c|}{ Good $=50-74,9 \%$} & \multicolumn{2}{|c|}{ Excellent $=75-100 \%$} \\
\hline & $\begin{array}{c}\text { Population } \\
\text { (individu } / \mathrm{km}^{2} \text { ) }\end{array}$ & $\begin{array}{l}\text { Rekriutmen rate } \\
\text { (individu/year) }\end{array}$ & $\begin{array}{l}\text { Populasi Lola } \\
\text { (individu/ } / \mathrm{km}^{2} \text { ) }\end{array}$ & $\begin{array}{l}\text { Rekriutmen rate } \\
\text { (individu/year) }\end{array}$ \\
\hline 2011 & 19.203 & 17.498 & 19.203 & 17.498 \\
\hline 2012 & 31.200 & 28.430 & 32.718 & 29.812 \\
\hline 2013 & 50.668 & 46.169 & 55.725 & 50.776 \\
\hline 2014 & 82.243 & 74.940 & 94.878 & 86.453 \\
\hline 2015 & 133.431 & 121,582 & 161.488 & 147.148 \\
\hline 2916 & 216.372 & 197.158 & 274.769 & 250.370 \\
\hline 2017 & 350.697 & 319.555 & 467.356 & 425.855 \\
\hline 2018 & 568.133 & 517.683 & 794.658 & 724.092 \\
\hline 2019 & 919.831 & 838.241 & 1.350 .717 & 1.230 .773 \\
\hline 2020 & 1.488 .831 & 1.356 .622 & 2.295 .092 & 2.091 .288 \\
\hline 2021 & 2.408 .355 & 2.194 .493 & 3.898 .404 & 3.552 .226 \\
\hline
\end{tabular}

Implication of this scenario is the needs of efforts to maintain this coral reef condition in the coastal area of Saparua Island which is now on standing in good and excellent condition. While for a location with fair to poor coral reef condition, it needs transplantation under expectation that in the future, T.niloticus resources or the other resources living in coral reef ecosystem can be sustainable maintained. Coral reef ecosystem management is for human interests, then many of its factors related to its interests should be considered [11]. It is not only one factor, but also all of the factors should be considered to avoid interest frictions, such as ecological, economy and social-cultural factor.

\section{Scenario of Sasi and Law Implementation Policy for T.niloticus Resources Management}

From the scenario simulation on contribution quantity of sasi and law implementation by $40 \%$ for T.niloticus resources protection activities, population increases from 19,203 individual $/ \mathrm{km}^{2}$ in 2011 to 118,903 individual $/ \mathrm{km}^{2}$ in 2021 . The same raise is also happened to fisherman income per year, from \pm IDR6,000,000.- to IDR 8,502,414.20/year. Then, if sasi and law implementation is increased to $60 \%$, it indicates the increase of T.niloticus population condition which is same as sasi and law implementation by $40 \%$. However, fisherman income level raises significantly to IDR12,409, 240.10/ year (Table 3).

Table 3. Simulation result of sasi and law implementation model toward T.niloticus population and fisherman income raise in Saparua Island

\begin{tabular}{|c|c|c|c|c|}
\hline \multirow[b]{2}{*}{ Year } & \multicolumn{2}{|c|}{ Application of UU \&Sasi $40 \%$} & \multicolumn{2}{|c|}{ Application of UU \&Sasi60\% } \\
\hline & $\begin{array}{c}\text { Population } \\
\text { (individu } / \mathrm{km}^{2} \text { ) }\end{array}$ & income (Rp/year) & $\begin{array}{c}\text { Population } \\
\text { (individu } / \mathrm{km}^{2} \text { ) }\end{array}$ & income (Rp/year) \\
\hline 2011 & 19.203 & $6.000 .000,00$ & 19.203 & $6.000 .000,00$ \\
\hline 2012 & 23.044 & $6.039 .222,40$ & 23.044 & $6.039 .222,40$ \\
\hline 2013 & 27.652 & $6.097 / 355,39$ & 27.653 & $6.104 .354,10$ \\
\hline 2014 & 33.183 & $6.179 .470,36$ & 33.183 & $6.206 .509,69$ \\
\hline 2015 & 39.820 & $6.293 .744,70$ & 39.820 & $6.364 .131,41$ \\
\hline 2916 & 47.784 & $6.447 .146,42$ & 47.784 & $6.601 .928,57$ \\
\hline 2017 & 57.341 & $6.650 .835,18$ & 57.341 & $6.982 .047,99$ \\
\hline 2018 & 68.809 & $6.926 .580,03$ & 68.810 & $7.522 .154,69$ \\
\hline 2019 & 82.571 & $7.297 .307,19$ & 82.572 & $8.409 .841,48$ \\
\hline 2020 & 99.086 & $7.801 .780,89$ & 99.487 & $9.871 .108,32$ \\
\hline 2021 & 118.903 & $8.502 .414,20$ & 118.906 & $12.409 .240,10$ \\
\hline
\end{tabular}

Implication of these two scenarios is when the existing sasi and law implementation policy today are improved to $40 \%$ or $60 \%$, it will not only contribute to T.niloticus population condition, but also will contribute to fisherman income level in Saparua Island.

\section{Model Validation}

Validation on this model is conducted by comparing model output (simulation result) and actual data as gained from secondary data for 3 years from 2011 to 2013. Model validation testing in this study uses statistical 
testing, i.e. AME (Absolutes Mean Error). Tested variables are the related variables in bioecological sub-model and sasi and law implementation existing in bioecological, social-economy-cultural, law and institutional submodel with the main and the same component, i.e. T.niloticus population. Based on testing score of T.niloticus resources management model validation in coastal waters of Saparua Island, it is seen that the AME score still lies in score of 5 to $10 \%$. Hence, it is concluded that the model has a good performance which also can be used to determine the purpose of its management policy.

\section{Conclusion}

\section{Conclusion}

Based on this study, it can be concluded that design build of T.niloticus resources management model in Saparua Island grounded on the created model simulation clarifies that if coral reef condition can be maintained in a good condition to an excellent one, T.niloticus population can be fixed and its recruitment rate will also be raised. Otherwise, if the sasi and law implementation performance are increased, T.niloticus population and fisherman income will also raise.

\section{Suggestion}

Based on this research in improving and elevating T.niloticus population condition which is declining continuously, it needs:

1. To maintain the coral reef condition to a good condition or an excellent one is by means of Regional Regulation Decision on allowable and illegal fishing gear equipments which will be operated around the coral reef ecosystem.

2. To increase the local wisdom (sasi) effectiveness in protecting T.niloticus resources through coordinating meeting implementation of government inter-institution and the existing custom in the village as well as the implementation of conference.

\section{References}

[1] Arafin, Z. 1993. Distribution, habitat and fishery of lola (Trochus niloticus) in Maluku Waters. Jur. Fak. Per. UNHAS.Makasar.1(3): 40 - 48

[2] Bralas, Y.1996. Formal Aspect of Model Validity and Validation in System Dynamics, System Dynamics Review, Vol 12 , No.3.

[3] Calquhoun,J.M. 2001. Habitat preferences of juvenile Trochus in Western Australia; Implications for stoch enhancement and assessment. SPC Trochus Information Bulletine No. 7 Juni 2001. p14-19.

[4] Daalen,V.danW.A.H.Thissen.2001.DynamicSystemModelling Continuous Models. Faculteit Techniek, Bestuuren Management (TBM). Technische Universiteit Delft.

[5] Dinas Kelautan dan Perikanan Provinsi Maluku. 2006.Laporan Statistik Perikanan Maluku. DKP.Ambon.

[6] Eriyatno. 2003. Ilmu sistem, meningkatkan mutu dan efektivitas manajemen. IPB Press. Bogor.hal 145.

[7] Ford, A, 1999. Modeling the Envoronment; An Introduction to System Dynamics Model of Environmental Systems.Island Press. Washington DC.401p

[8] Hartrisari.2007. Sistem dinamik: Konsep sistem dan pemodelan untuk industri dan lingkungan.SEMEO [6]

[9] Heslinga, G.A. 1981b. Larva Development, Settlement and Metamorphosis of the Tropical Gastropod Trochus niloticus.Malacologia, Manila.20 (2): 349-357.

[10] Hoang D.H., H.T.T Tuyen and Hoang Duc Lu. 2008. Growth rate of Trochus niloticus(L.,1767) fed different food types.SPC Trochus Information Bulletin.New Caledonia: 14 (7-11).

[11] Kordi,K.H.G., 2002.Ekosistem terumbu karang; Potensi, Fungsi dan Pengelolaan.PT Rineka Cipta. Jakarta.212 hal.

[12] Muhammadi, E. Aminullah, dan B.Soesilo.,2001.Analisis Sistem Dinamis Lingkungan Hidup, Sosial, Ekonomi, dan Manajemen. UMJ Press, Jakarta.

[13] Noor, R. 2009. Model pengelolaan kualitas lingkungan berbasisi daya dukung (Carrying Capacity) perairan teluk bagi pengembangan budidaya KJA ikan kerapu (Studi kasus di teluk Tamiang Kabupaten Kota Baru Kalimantan Selatan). Disertasi Doktor. Sekoloh Pascasarjana IPB.Bogor.145 hal.

[14] Soparue,Ch. 2008. Strategi pengelolaan sumberdaya lola(Trochus niloticus)di perairan wilayah ulayat negeri Nolloth, Kecamatan Saparua Kabupaten Maluku Tengah. Thesis. Unpatti.Ambon.111 hal.

[15] Yi, S.K. and C.J.Lee, 1997. Effect of temperature and salinity on the oxygen consumption and survival of Hathcery-reared juvenile top shell Trochus niloticus (Mollucs:Gastropoda). ACIAR Proceedings (79): 69 - 75. 